\title{
HUBUNGAN RIWAYAT PERDARAHAN DENGAN PERDARAHAN POSTPARTUM
}

\author{
Fatimah Thursina Sari ${ }^{1}$, A.Fahira Nur ${ }^{2}$ \\ ${ }^{1}$ Mahasiswa Kebidanan STIKES Widya Nusantara Palu \\ ${ }^{2}$ Bagian Kebidanan STIKES Widya Nusantara Palu
}

${ }^{\star} E$-mail : fatimahthursinas.fs@gamil.com

Kematian ibu adalah kematian seorang wanita yang terjadi pada saat kehamilan,bersalin atau 42 hari setelah persalinan dengan penyebab langsung atau tidak langsung terhadap persalinan. Perdarahan post partum adalah salah satu faktor penyebab langsung kematian ibu yang sulit untuk ditangani. Sehingga masih menjadi masalah utama bagi kesehatan. Faktor-faktor yang dapatmempengaruhi perdarahan postpartum yaitu partus lama,paritas,peregangan uterus yang berlebihan,oksitosin drip,anemia dan persalinan dengan tindakan. Kematian ibu akan dapat tertangani dengan baik,jika faktor-faktor tersebut dapat dicegah dan ditangani secara maksimal ${ }^{1,3}$.

Berikut ini penulis akan membahas tentang hubungan riwayat perdarahan dengan perdarahan postpartum.

\section{Tinjauan Tentang Riwayat Perdarahan}

Riwayat persalinan yang buruk dengan riwayat perdarahan postpartum sebelumnya akan memberikan dampak yang buruk pada organ reproduksi wanita. Sehingga tingkat kewaspadaan harus dilakukan jika sudah mempunyai riwayat persalinan yang buruk sebelumnya. Ibu yang mempunyai riwayat perdarahan berisiko lebih besar untuk mengalami perdarahan postpartum daripada dengan ibu yang tidak mempunyai riwayat perdarahan. Riwayat persalinan yang sebelumya dapat menyebabkan penyulit pada persalinan selanjutnya ${ }^{5}$.

\section{Tinjauan Tentang Perdarahan Post Partum}

Perdarahan post partum adalah perdarahan lebih dari $500 \mathrm{cc}$ yang terjadi setelah bayi lahir pervaginam atau lebih dari $1000 \mathrm{cc}$ setelah 
persalinan abdominal dalam 24 jam dan sebelum 6 minggu setelah persalinan.Perdarahan post partum dibagi menjadi perdarahan primer yaitu perdarahan yang terjadi dalam 24 jam pertama dan disebabkan oleh atonia uteri,robekan jalan lahir dan sisa plasenta.Sedangkan perdarahan sekunder adalah perdarahan yang terjadi setelah 24 jam persalinan disebabkan oleh sisa plasenta ${ }^{1}$.

Faktor-faktor yang dapat mempengaruhi perdarahan post partum yaitu umur,paritas,status gizi,kelainan darah,bayi besar,gemeli,induksi persalinan dan mempunyai riwayat perdarahan postpartum. Gejala klinis dari perdarahan postpartum berupa perdarahan terus menerus,denyut nadi menjadi cepat dan melemah,tekanan darah menurun,pasien tampak pucat,sesak dan berkeringat.Perdarahan postpartum yang tidakdapat segera ditangani akan mengakibatkan syok dan mengurangnya kesadaran karena keluarnya darah yang banyak ${ }^{1,2}$.

\section{Tinjauan Tentang Riwayat Perdarahan Terhadap Perdarahan} Postpartum

Riwayat persalinan yang sebelumnya dapat mengakibatkan penyulit pada persalinan selanjutnya. Salah satunya yaitu ibu yang pernah mengalami perdarahan post partum akan meningkatkan risiko terjadinya perdarahan post partum pada persalinan selanjutnya. Apalagi perdarahan post partum sebelumnya diakibatkan karena gangguan pembekuan darah².

Perdarahan post partum dapat terjadi karena kesalahan pada saat penanganan kala III persalinan dengan memijat uterus dan mendorongnya ke bawah pada saat melahirkan plasenta,pembekuan darah akibat dari hipofibrinogenemia (solusio plasenta,retensio plasenta,retensi janin mati dalam uterus,emboli air ketuban). Apabila sebagian plasenta lepas dan sebagiannya lagi belum, maka terjadi perdarahan karena uterus tidak berkontraksi dengan baik pada batas antara dua bagian tersebut. Kemudian apabila sebagian besar dari plasenta sudah lahir akan tetapi sebagian plasenta masih melekat pada dinding uterus,dapat menimbulkan perdarahan pada masa nifas. 
Perlukaan pada jalan lahir juga dapat mengakibatkan perdarahan ${ }^{4}$.

Hasil penelitian membuktikan bahwa terdapat hubungan antara riwayat perdarahan postpartum dengan perdarahan postpartum. Bahwa wanita yang mempunyai riwayat perdarahan postpartum sebelumnya akan berpeluang mempunyai 3,3 kali mengalami perdarahan postpartum pada persalinan selanjutnya daripada wanita yang tidak mempunyai riwayat perdarahan ${ }^{2}$.

Hasil penelitian menunjukkan bahwa riwayat perdarahan ada hubungannya dengan kejadia perdarahan postpartum. Ibu yang mempunyai riwayat perdarahan akan berisiko 6,025 kali lebih besar mengalami perdarahan postpartum daripada ibu yang tidak mempunyai riwayat perdarahan. Upaya untuk mencegah terjadinya perdarahan postpartum pada persalinan berikutnya yaitu tenaga kesehatan harus memberikan penyuluhan atau pengetahuan lebih terkait perdarahan postpartum,menganjurkan ibu untuk memeriksakan kehamilannya secara teratur dan melahirkan di tenaga kesehatan atau fasilitas kesehatan yang menyediakan bank darah sehingga jika terjadi perdarahan postpartum dapat tertangani dengan baik ${ }^{2,5}$. 


\section{DAFTAR PUSTAKA}

1. Yekti Satriyandari dan Nena Riski Hariyati (2017). Fakto-Faktor Yang Mempengaruhi Kejadian Perdarahan Postpartum. Jurnal of Health Studies Vol.1 No.1, Maret 2017 : 49-64.

https://ejournal.unisayogya.ac.id/ejournal/index.php/JHeS/article/vie wFile/185/121 diakses pada tanggal 12 Oktober 2019 Pukul 09.41 WITA.

2. Anisa Fitriana dan Nunik Puspitasari (2015). Hubungan dan Faktor Risiko Partus Lama Riwayat Perdarahan Postpartum dan Berat Bayi Lahir Besar dengan Kejadian Perdarahan Postpartum. Jurnal Biometrika dan Kependudukan Vol. 4 No. 2, Desember 2015 : 118124.

http://journal.unair.ac.id/download-fullpapers-jbk6b630f558full.pdf diakses pada tanggal 12 Oktober 2019 Pukul 21.17 WITA.

3. Eka Yuliana dan Atik Setiyaningsih (2014). Hubungan Jarak Kelahiran Dengan Kejadian Perdarah Postpartum Primer Di BPS Hermin Ampel Boyolali. Jurnal Kebidanan Vol. VI No.01, Juni 2014 http://www.ejurnal.stikeseub.ac.id/index.php/jkeb/article/view/128/1 27 diakses pada tanggal 12 Oktober 2019 Pukul 23.16 Wita.

4. Sarmini Moedjiarto (2011). Karakterisktik ibu Yang Berhubungan Dengan Perdarahan Post Partum Di RB Medika Utama Wonokupang Balongbendo Sidoarjo. Jurnal Hospital Majapahit Vol. 3 No. 1, Februari 2011.

http://ejournal.stikesmajapahit.ac.id/index.php/HM/article/download/ 38/34 diakses pada tanggal 12 Oktober 2019 Pukul 23.20 WITA

5. A.Fahira Nur,Abd.Rahman,Herman Kurniawan (2019). Faktor Risiko Kejadian Perdarahan Postpartum Di Rumah Sakit Umum (RSU) Anutapura Palu. Jurnal Kesehatan Tadulako Vol. 5 No. 1, Januari $2019: 1-63$

http://jurnal.untad.ac.id/jurnal/index.php/HealthyTadulako/article/view/12 $\underline{622 / 9765}$ diakses pada tanggal 02 Oktober 2019 Pukul 08.54 WITA. 